\title{
Ketrampilan Bidan dalam Melakukan Pemeriksaan Derajat Diastasis Rekti Abdominalis pada Ibu Nifas
}

\author{
Rizki Amalia ${ }^{1}$, Elly Dwi Masita ${ }^{1}$ \\ ${ }^{1}$ Program Studi DIII Kebidanan, Fakultas Keperawatan dan Kebidanan Universitas Nahdlatul Ulama Surabaya
}

Corresponding author: Rizki Amalia (amalia24@unusa.ac.id)

Received 16 August 2019; Accepted 20 August 2019; Published 5 September 2019

\begin{abstract}
ABSTRAK
Diastasis rekti abdominalis Sering tidak terdeteksi dan tidak dilakukan pemeriksaan di tenaga kesehatan. Berdasarkan data yang diperoleh dari studi pendahuluan yang dilakukan penulis di PMB Mei kurniawati Maret Tahun 2019 terdapat 25 ibu nifas didapatkan informasi bahwa ibu nifas yang tidak pernah di periksa diastasis rekti abdominisnya. Dengan demikian penulis tertarik untuk melakukan penelitian lebih lanjut, sehingga peneliti mengambil judul "Ketrampilan Bidan terhadap pemeriksaan derajat diastasis rekti abdominalis pada ibu nifas". Tujuan penelitian ini untuk menganalisis ketrampilan bidan dalam melakukan pemeriksaan derajat diastasis rekti abdominalis. Penelitian ini merupakan penelitian kualitatif dengan menggunakan metode purposive sampling. Penelitian dilakukan sejak 1 April 2019 sampai dengan 30 Mei 2019 dengan teknik wawancara mendalam dan observasi. Informan penelitian adalah Bidan pelaksana di Praktek Mandiri Bidan Mei Kurniawati, Sawah pulo, Ujung, Surabaya. Hasil analisis menunjukkan bahwa semua bidan belum pernah mendapatkan pelatihan atau sosialisasi tentang pemeriksaan derajat diastasis rekti abdominalis pada ibu nifas dan selama ini tidak pernah dilakukan pemeriksaan derajat diastasis rekti Abdominalis pada ibu nifas,bidan belum mengetahui tujuan dan manfaat dilakukan pemeriksaan derajat diastasis rekti abdominalis pada ibu nifas sesuai standar, belum semua bidan mematuhi standar pelayanan nifas yang sudah ditetapkan, masih terdapat sarana dan prasarana yang belum memadai untuk melakukan pemeriksaan derajat diastasis rekti abdominalis sesuai standar, bidan telah memiliki pengetahuan yang cukup mengenai deteksi risiko dan mampu melakukan deteksi risiko pada ibu nifas. Dilakukan pelatihan dan sosialisasi pada semua bidan pelaksana terkait pemeriksaan derajat diastasis rekti abdominalis pada ibu nifas.
\end{abstract}

Kata Kunci: Keterampilan bidan, pemeriksaan DDR

Copyright @ 2019 Institut Ilmu Kesehatan STRADA Indonesia All rights reserved.

This is an open-acces article distributed under the terms of the Creative Commons Attribution-ShareAlike 4.0 International License.

\section{PENDAHULUAN}

Puerperium/Masa nifas adalah masa kembali pulih mulai dari selesai persalinan hingga alatalat kandungan kembali seperti sebelum hamil. Lama masa nifas ini yaitu 6-8 minggu. Bobak (2000) menjelaskan bahwa selama kehamilan otot dinding perut meregang dan akhirnya kehilangan 
sedikit tonus otot. Diastasis rektus abdominis adalah regangan pada otot rektus abdominis akibat pembesaran uterus. Regangan ini menyerupai celah memanjang dari prosessus Xiphoideus ke umbilikus sehingga dapat diukur panjang dan lebarnya.

Beberapa wanita pasca melahirkan merasa longgar pada bagian dinding perut karena bagian abdominal melebar selama kehamilan dan persalinan. Kondisi ini dinamakan diastasis recti. Dibutuhkan waktu sekitar 4 hingga 8 minggu setelah melahirkan untuk mengatasinya. Berhati-hati jika Anda mulai melakukan latihan fisik untuk bagian perut karena Anda bisa berisiko melukai otot di bagian ini. Jadi pastikan perut Anda siap sebelum Anda memulai melakukan gerakan berikut ini:Berbaring telentang dengan lutut ditekuk, Tempatkan jari tangan kiri, dengan telapak tangan menghadap Anda di atas pusar. Tempatkan tangan kanan di atas paha, Tarik nafas lalu keluarkan. Saat mengeluarkan nafas, angkat kepala dan bahu menjauhi lantai dan geser tangan kanan dari paha menuju lutut. Latihan ini akan membuat otot bagian perut menjadi ketat, dan Anda akan dapat merasakan adanya celah saat otot terpisah.

Berdasarkan data yang diperoleh dari studi pendahuluan yang dilakukan penulis di PMB Mei kurniawati Maret Tahun 2019 terdapat 25 ibu nifas didapatkan informasi bahwa ibu nifas yang tidak pernah di periksa diastasis rekti abdominisnya. Dengan demikian penulis tertarik untuk melakukan penelitian lebih lanjut, sehingga peneliti mengambil judul "Ketrampilan Bidan terhadap pemeriksaan derajat diastasis rekti abdominalis pada ibu nifas".

\section{METODE}

Pada penelitian ini desain penelitian yang digunakan adalah penelitian lapangan (field research) yang dalam pengumpulan datanya dilakukan dengan mencari data secara langsung dari lokasi penelitian. Dengan pendekatan fenomenologi yang merupakan pemaknaan etika dalam berkonsep dan berteori. Tidak hanya menampilkan teori dan konseptualisasi yang sekedar anjuran sehingga akan menghasilkan deskripsi mengenai gambaran situasi yang di teliti serta pemaknaan yang terkandung dalam data hasil pengamatan. Spesifikasi penelitian ini menggunakan penelitian deskriptif analisis yaitu penyajian data yang dalam bentuk kata dan bahasa secara holistic pada suatu konteks khusus yang alamiah dengan melakukan analisis secara induktif dengan menggunakan pendekatan fenomenologi, jadi penelitian yang dilakukan ini guna menyelidiki suatu proses yang berkaitan dengan pemeriksaan dejat diastasis rekti abdominalis pada ibu nifas, dengan Populasi dan sampel Sampel diambil menggunakan total sampling. Penelitian dilakukan di PMB Mei Kurniawati Surabaya. Dilaksanakan selama 6 bulan. Peneliti mengajukan permohonan pengambilan data dari LPPM Universitas Nahdatul Ulama Surabaya kepada bidan Mei kurniawati , setelah mendapatkan ijin pengambilan data kemudian melakukan pendekatan dengan ibu nifas dan menjelaskan tentang metode pemeriksaan serta melakukan informed consent, Instrumen penelitian untuk variabel pelaksanaan derajat diastasis rekti abdominalis dan metode menggunakan SOP, Pengumpulan data dilakukan secara langsung / data primer, dengan tekhnik observasi, tekhnik interview, dan tekhnik dokumentasi.

\section{HASIL}

Dari 10 bidan hampir semua tidak pernah melakukan pemeriksaan derajat diastasis rekti abdominalis pada ibu nifas hal ini bertentangan dengan teori dari Ari sulistyawati (2010) bahwa pemeriksaan nifas yang komprehensif membantu menurunkan angka kematian ibu di Indonesia yang saat ini di temukan faktor penyebab kematian terbanyak adalah pada saat masa nifas.

Ketrampilan bidan disini di ukur dari bagaimana pendidikan bidan mengetahui pengertian pemeriksaan derajat diastasis rekti abdominalis beserta tujuan dan cara memeriksanya ternyata dalam hal ini bidan di PMB Mei kurniawati sama sekali tidak pernah mendengar teori tersebut. Hasil wawancara mendalam :

Bidan 1:

'apa itu bu derajat diastasis rekti abdominalis ?' saya tidak pernah mendegar sebelumnya"

Bidan 2:

'kok saya kuliah dulu gak ada ya bu"

Bidan 3 : 
"Saya belum pernah melakukannya bu"

Bidan 4:

"Di tempat kami ini tidak pernah kami periksa derajat diastasis rekti nya bu"

Bidan 5

"Saya sempat dapat materi kuliah tersebut"

Bidan 6 :

"Selama praktek disini saya belum mencobanya bu"

Bidan 7:

"Dulu saat praktek laboratorium antar teman saya sempat coba tapi masih bingung bu"

Bidan 8 :

"Ternyata perlu ya bu pemeriksaan derajat diastasis rekti abdominalis"

Bidan 9:

'Saya kira nifas itu hanya periksa TFU saja bu"

Bidan 10 :

"Wah pengen mencoba tapi takut melanggar SOP tempat praktek bu"

Hasil analisis menunjukkan bahwa semua bidan belum pernah mendapatkan pelatihan atau sosialisasi tentang pemeriksaan derajat diastasis rekti abdominalis pada ibu nifas dan selama ini tidak pernah dilakukan pemeriksaan derajat diastasis rekti Abdominalis pada ibu nifas,bidan belum mengetahui tujuan dan manfaat dilakukan pemeriksaan derajat diastasis rekti abdominalis pada ibu nifas sesuai standar, belum semua bidan mematuhi standar pelayanan nifas yang sudah ditetapkan, masih terdapat sarana dan prasarana yang belum memadai untuk melakukan pemeriksaan derajat diastasis rekti abdominalis sesuai standar, bidan telah memiliki pengetahuan yang cukup mengenai deteksi risiko dan mampu melakukan deteksi risiko pada ibu nifas.

2 Bidan lulusan DIII Kebidanan sama sekali tidak pernah mendapatkan materi derajat diastasis rekti abdominalis, 2 Bidan magang lulusan DIII Kebidanan sempat mendengar istilah tersebut dan tidak faham cara memeriksanya,6 mahasiswa Bidan praktek pernah mendapatkan materi namun tidak di aplikasikan.

\section{PEMBAHASAN}

Penelitian serupa pernah dilakukan Lisa Marniyati di Program Pascasarjana Ilmu Kesehatan Masyarakat Universitas Sriwijaya, Palembang dengan judul Pelayanan Antenatal Berkualitas dalam Meningkatkan Deteksi Risiko Tinggi pada Ibu Hamil oleh Tenaga Kesehatan di Puskesmas Sako, Sosial, Sei Baung dan Sei Selincah di Kota Palembang.

\section{KESIMPULAN}

Peneliti menyimpulkan bahwa pemeriksaan Derajat diastasis rekti abdominalis belum sesuai harapan, indikasi yang menunjukkan adalah masih rendahnya tingkat pencapaian pemeriksaan derajat diastasis rektti abdominalis dan edukasi diastasis exercise hal ini dipengaruhi oleh beberapa macam faktor diantaranya kemampuan pegetahuan bidan penulis member saran Tenaga kesehatan untuk selalu tetap memeriksa derajat diastasis rekti abdominalis, Memberikan pendidikan kesehatan pentingnya memperhatikan derajat diastasis rekti abdominalis menghindari komplikasi yang terjadi.

\section{Acknowledgments}

Terima kasih pihak ristekdikti atas sumbangsih dana dengan nominal 9.200.000 untuk pelaksanaan penelitian ini, pihak LPPM yang telah memberikan ijin dan dukungan administrative lainnya, pihak PMB Mei Kurniawati, Pihak responden penelitian ini semua ibu nifas,teman sejawat dosen UNUSA, suami anak serta keluarga besar untuk dukungannya. 


\section{REFERENSI}

Acharry, N., Krishanan, K., R. (2015). Latihan perut dengan bracing. Sebuah Efikasi terapeutik dalam mengurangi Diastasis rekti di antara wanita pasca melahirkan.Jurnal Internasional Fisioterapi vol 3 no 2: 9991005 .

Active Pregnancy Active Mum. (2014). Diunduh pada $25 \quad$ Juli 2019 dari:http://www.activemum.com.au/attachments/Abdominal_seperati on_hand_out.pdf. Diastasis rektus abdominis (perut pemisahan otot) dan menilai pelatihan diastasis rektus abdominis.

Albrecht, M., Eberhardt, L., Horn, L., Donnelly, Y., C., Lowe, D. (2012). Diastasis dari rektus abdominis: survei wanita spesialis kesehatan untuk fisik saat ini terapi klinis;berlatih untuk postpartum womens. Jurnal kesehatan wanita dan terapi fisik. vol 3, no 131- 141.

Berdzik, \& Dąbrowski, S. (2009). Fisioterapi dalam diastasis rektus otot perut pada wanita selama kehamilan dan pasca persalinan. Jurnal dari Fizjoterapia volume 17 no 4: hal 67-70.

Biossonnault, S., J., \& Blaschak, J., M. (2018). Insidensi diastasis recti abdominis selama tahun subur. Jurnal dari Amerika Fisik Terapi Association. Vol 68:hal 1082- 1086.

Chiarello, M., C., Falzone, A., L., Mc Caslin E., K., Patel, M., \& Ulery, K. (2015). Pengaruh Program Latihan pada Diastasis Recti Abdominis pada Wanita hamil. Jurnal terapi fisik kesehatan wanita. vol 29 no 1:hal 11-16.

Cynthia, M., Chiarello, J., Mcauley, A. (2013). Validitas Bersamaan Kaliper dan Pencitraan Ultrasound Ukur Jarak Interrecti. Jurnal dari ortopedi \& terapi fisik olahraga. Vol 43 no 7; halaman 495-503.

Fac. Ph. Th. Universitas Kairo. (2003). Latihan pasca natal. Perempuan dan layanan kesehatan yang baru lahir, raja Edward rumah sakit memorial, Austrelia barat.Tersediadari:http://kemh.health.wagov.au/brochures/consumers/postnatal_exercise.pdf vol 8 no 1.

Gari Cunningham, F. dkk. (2012). Obstetri Williams.Jakarta: EGC.

Jurnal Ilmu Kesehatan \& Penelitian Internasional (www.ijhsr.org) 191 Vol.6;di akse : 6; Juni 2019 Jurnal pendidikan perinatal. 2000:vol 9 no 1 : hal 1-13.

Kisner, C., \& Colby, L., A. (2007). Latihan terapeutik, kesehatan wanita: kebidanan dan dasar panggul. edisi 5 hal 797-824.

Mekawy, H., Eldeeb, M., A., Lythy, M., A., Begawy, A. (2013). Pengaruh Perut Latihan versus Perut Mendukung Sabuk pada Postpartum Perut Efisiensi dan Pemisahan Rectus. International Scholarly and Scientific Research \& Innovation.vol 7 no 1: hal 44- 48.

Mentle, J., Haslam, J., \& Barton, S. (2004). Fisioterapi dalam kebidanan dan ginekologi. Edisi kedua.

Mota, P. (2014). Morfologi dan adaptasi fungsional dari perut dinding selama kehamilan dan dalam postpartum period.di unduh 2019. dari: https: //www.repository.utl.pt/bitstream / 10400.5 / 8347/1 / Manuscript.pdf.

Misha, A., Maria, L., Umar, M., \& Kanwal, R. Prevalensi diastasis rekti di antara wanita hamil yang tampil di tempat suci keluarga RSUD Rawalpindi. Jurnal internasional rehabilitasi sains.vol 03, no 1: hal 26-31.

Nursalam. (2011). Metodologi Penelitian Ilmu Keperawatan. Jakarta: Salemba Medika.

Parkee, A., M., lynn, M., A., \& Dugan, S. (2008). Diastasis rektus abdominis dan kayu nyeri panggul dan disfungsi - apakah mereka terkait. Jurnal kesehatan perempuan terapi fisik. Vol 9 no 1: hal 32.

Pascoal, A., G., Dionisio, S., Cordeiro, F., Jarak, M., P. (2014). Inter recti dalam wanita pasca melahirkan dapat dikurangi dengan kontraksi isometrik perut otot; Kontrol kasus pendahuluan belajar. Diterbitkan oleh Elsevier. Fisioterapi: 100 344-348. 
Pelatihan dan lembaga kebugaran militer; Diastasis recti: sebuah ikhtisar; 2015; tersedia dari: [http: // boot camp militery fitness institute. Com / cedera / diastasis-recti an ikhtisar /] Benjamina DR, ATM van de Water.

Peiris, C., L. (2014). Efek latihan diastasis otot rektus abdominis pada periode antenatal dan postnatal: a tinjauan sistematis. Diterbitkan oleh Elsevier. Fisioterapi vol 100 hal 1-8.

Pivarnik, J., Chambliss, O., H., Clapp, F., J., Dugan, A., S., Hatch, C., M., Lovelady, A., C.,et al. Dampak pada aktivitas fisik selama kehamilan dan post partum pada kronis risiko penyakit. Jurnal orang Amerika Perguruan Tinggi Kedokteran Olahraga. Obat \& Sains dalam Olahraga \& Latihan. 2006; vol 10.no 1 hal 1249.

Saleha, \& Sitti. (2009). Asuhan Kebidanan pada Masa Nifas. Jakarta: Salemba Medika.

Sapsford, R., \& Bullock-Saxton, J. (2008). Kesehatan Markwell S. Perempuan: sebuah teks-Pesan untuk fisioterapis. Edisi 1. London: WB Saunders Company Ltd.

Sebuah uji coba terkontrol secara acak. Jurnal terapi fisik Amerika asosiasi. 2012, 92; 78 / -790. Kosery M.EL S *, Abd El-Aziz A, Farouk A. Latihan otot perut program dan / atau stimulasi listrik di diastasis recti postnatal. Fakultas fisioterapi, Universitas Kairo. Vol 12 no 2, 2007.

Shappard, S. (2016). Peran transversus abdominis dalam koreksi post partum rekti lintas divarication. Jurnal dari asosiasi fisioterapis carteran dalam kesehatan wanita. Vol 1 no 4 hal 214-216.

Syaifuddin, Abdur, Bari, dkk. (2010). Buku Panduan Praktis Pelayanan Kesehatan Maternal Dan Neonatal.

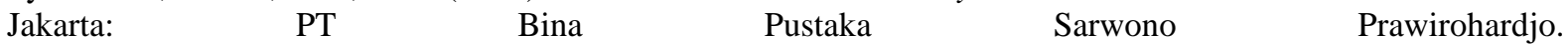

Youssef, M., A., Sabbour, A., D., Kamel, M., R. (2009). Aktivitas Otot di Atas dan Bawah Bagian-bagian Rectus Abdominis Selama Latihan Perut dalam Postnatal Wanita Memiliki Diastasis Recti. Banteng. 